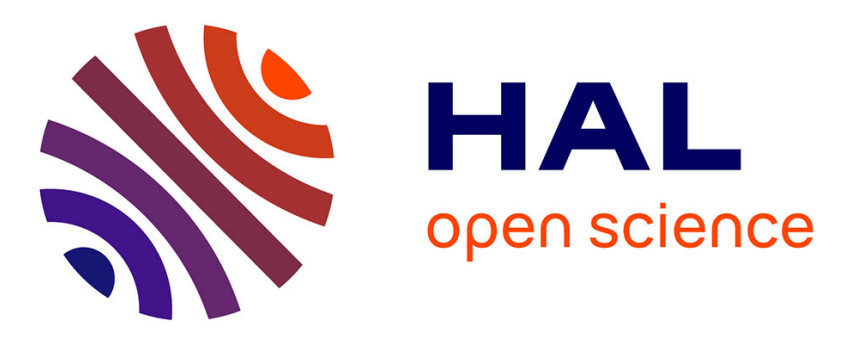

\title{
What's the middle ground? Institutionalized vs. emerging water-related stakeholder engagement processes
}

\author{
E. Hassenforder, D. Clavreul, A. Akhmouch, Nils Ferrand
}

\section{- To cite this version:}

E. Hassenforder, D. Clavreul, A. Akhmouch, Nils Ferrand. What's the middle ground? Institutionalized vs. emerging water-related stakeholder engagement processes. International Journal of Water Resources Development, 2018, 35 (3), pp.525-542. 10.1080/07900627.2018.1452722 . hal-02608069

\section{HAL Id: hal-02608069 \\ https: / hal.inrae.fr/hal-02608069}

Submitted on 16 May 2020

HAL is a multi-disciplinary open access archive for the deposit and dissemination of scientific research documents, whether they are published or not. The documents may come from teaching and research institutions in France or abroad, or from public or private research centers.
L'archive ouverte pluridisciplinaire HAL, est destinée au dépôt et à la diffusion de documents scientifiques de niveau recherche, publiés ou non, émanant des établissements d'enseignement et de recherche français ou étrangers, des laboratoires publics ou privés. 


\section{What's the Middle Ground? Institutionalised vs. Emerging Water- related Stakeholder Engagement Processes}

Emeline Hassenforder ${ }^{1}$, Delphine Clavreul $^{2}$, Aziza Akhmouch ${ }^{2}$, Nils Ferrand ${ }^{1}$

${ }^{1}$ G-EAU, Irstea, AgroParisTech, Cirad, IRD, Montpellier SupAgro, Univ Montpellier, Montpellier, France

${ }^{2}$ Water Governance Programme, Organisation for Economic Co-operation and Development, Paris, France

Correspondence: Delphine.Clavreul@oecd.org; Tel.: +331452487 73

International Journal of Water Resources Development

Received 22 Dec 2016, Accepted 10 Mar 2018, Published online: 07 Jun 2018

https://www.tandfonline.com/doi/full/10.1080/07900627.2018.1452722?scroll=top\&ne $\underline{\text { edAccess }=\text { true }}$ 


\title{
What's the Middle Ground? Institutionalised vs. Emerging Water- related Stakeholder Engagement Processes
}

\author{
In this day and age, it is widely argued that stakeholder engagement in \\ water-related decision-making processes yields many benefits, including \\ legitimacy, acceptance, and trust. Key legal frameworks, such as the \\ European Water Framework Directive and the Aarhus Convention have \\ spurred the emergence of formal forms of stakeholder engagement. \\ Conjunctively, many engagement processes are spontaneous and self- \\ organised. This article investigates the strategies used in formal (i.e. \\ government-led) and informal (i.e. bottom-up) engagement processes in \\ search of a middle ground. To this end, case studies in the Netherlands, the \\ United States, Uganda and Ethiopia are analysed using the OECD \\ Checklist of stakeholder engagement. We conclude with a reflexion on the \\ ways forward to make formal and informal stakeholder engagement \\ complementary.
}

Keywords: stakeholder engagement; governance; public participation; institutional analysis; water policies

\section{Introduction}

When tracing the history of public participation and stakeholder engagement, academic literature reveals a range of disciplines, fields of study and methodologies. Founding concepts have been forged by philosophers and socio-political theorists, such as Mowday (1979), Habermas (1989), and Ostrom (1990), whose approaches to institutional analysis have demonstrated that solidarity-based economies are promising alternatives to traditional state-centred command-and-control economic solutions to pressing social and ecological problems. More applied contributions have come from the fields of science, technology and environment policy. These contributions have investigated different typologies and processes of engagement-moving from participation as an end in itself, notably Arnstein's Ladder on Citizen Participation (Arnstein, 1969), to considering it as a means to an end as in the case of Fung's Democracy Cube (Fung, 2006). Structured around axes of authority and power, types of 
participants and communication and decision modes, the democracy cube aims to inform institutional design choices for public participation planning activities.

In the environmental field, stakeholder engagement has increasingly been considered as an integral part of sound water governance over the past decades (OECD, 2015; UNESCAP, 2009). Efforts to design more inclusive processes are becoming more prevalent in the water policy landscape. Legislation, guidelines and standards at various levels - most notably the EU Water Framework Directive (European Parliament, 2000) and the Aarhus Convention (UNECE, 1998) - have spurred the emergence of formal, or even institutionalised, forms of stakeholder engagement in the water sector. Increasingly, either because of legal requirements or on a voluntary basis, public authorities, service providers, regulators, basin organisations and donors have included requirements for co-operation, consultation or awareness-raising in their operational rules and procedures. This tendency is also the result of water practitioners' better understanding that stakeholder engagement is instrumental in two ways. First, it helps shape water policies so as to meet the needs of people and places. Second, it informs and supports the delivery of outcomes that matter to stakeholders in an accountable, innovative and cost-effective manner. Organisations are referring to such stakeholder engagement in their overarching principles and policy. Stakeholder engagement is rightly considered as an important driver of legitimacy, social ownership, acceptance, and trust in government decisions.

However, the shift toward more structural stakeholder engagement can also have a detrimental impact. For instance, it may lead to box-ticking approaches whereby engagement is only carried out to comply with existing legal frameworks and rules. In cases where the level of engagement is limited to the minimum required, benefits of stakeholder engagement will also be limited. Other barriers hindering the effective contribution of stakeholders to water-related decision-making include, but are not limited to: i) lack of clarity on the use of stakeholders' inputs, which can result in mistrust; ii) lack of resources to take part in the process; iii) exclusion of opposing parties; and iv) weak disclosure of information. These impediments often lead to risks of consultation fatigue or capture. They call for alternative mechanisms and processes that pay more attention to the growing roles of the public in general and water users in particular. 
In many places, more spontaneous, informal approaches to stakeholder engagement are common practice. They are a heritage of centuries-old practices of self-organising initiatives to manage water. In the Netherlands, the so-called Dutch polder approach is a consensus decision-making model that has been applied since the Middle Ages and has proven crucial to building dykes, draining swamps and creating land out of water in a country mostly located below sea level (Havekes et al., 2004; Lazaroms and Poos, 2004, OECD, 2014). Spain also has a long and rich history with regard to the formation of irrigators and water-user communities, which are exemplary self-governance systems (Garrido, 2014). They have paved the way to current spontaneous initiatives that typically help build a sense of community. They provide an open atmosphere that generally makes participants more willing to discuss issues that may not have come to light through more formal engagement processes. But they also have limits. Spontaneous engagement processes may have more difficulties turning the views and concerns voiced into actual contributions to decision-making and implementation, and are often limited to consultative purposes or information sharing. Because selforganising initiatives often lack governmental support, they tend to remain marginalised.

It is apparent that neither formal nor informal forms of engagement processes are the panacea to address the need to involve stakeholders in water policies and projects. Water governance is a shared responsibility, not only a government issue. Designing and implementing water policies should be carried out in co-operation with the broader range of stakeholders. However, making stakeholder engagement happen on the ground in an effective, cost-efficient and inclusive way, remains a major challenge. Both formal and informal approaches contend with shortcomings, all the while demonstrating valuable attributes that contribute to effective stakeholder engagement. In parallel, the different degrees of formality that can exist in stakeholder engagement are not always clear-cut and imply different requirements (e.g. resources, support, skills) and can lead to different results in terms of how effective engagement is in reaching the expected outcomes. Efforts are therefore needed to strengthen the relationship between local stakeholders and public authorities, and to focus on the inter-linkages and complementarities between (formal) governmental-led action and (informal, bottom-up) collective action, thus seeking for a middle ground. This article aims to analyse the 
strategies used in formal (i.e. government-led) and informal (i.e. bottom-up) engagement processes to seek for such middle ground. The strengths and shortcomings of these strategies are highlighted and examined. A discussion follows on the nature of these middle ground strategies and provides recommendations on how to implement them in practice.

The article relies on the analysis of four case studies. The first two cases concern engagement processes that are embedded in legal and institutional frameworks - the Delta Programme in the Netherlands and the Chesapeake Bay Program in the United States - while the other two cases concern more spontaneous and self-organised engagement processes - the Rwenzori region Mpanga river management plan in Uganda and the Gumera catchment management plan in Ethiopia. The Ugandan and Ethiopian participatory processes were developed as part of a European Union-funded research project called AfroMaison (AfroMaison project, 2011-2014). As such, they are not fully self-organised as they received support from international researchers involved in the project. Yet, they are spontaneous as they stem from a decision by local stakeholders, especially researchers, to apply to the AfroMaison project in order to be able to implement participatory processes in their territory.

\section{Multi-level water governance and the challenge of stakeholder engagement}

Multi-level governance and stakeholder engagement are intrinsically linked. Governance implies making decisions about issues at stake and therefore invariably requires the engagement of stakeholders, i.e. the process by which any person or group who has an interest or stake in a water-related topic is involved in the related activities, decision-making and implementation processes. The person or group may be directly or indirectly affected by water policy and/or be able to influence the outcome positively or negatively (OECD, 2015). For the purpose of this work, we have adopted the following definition of multi-level governance: the explicit or implicit sharing of policymaking authority, responsibility, development and implementation at different administrative and territorial levels, i.e.: i) across different ministries and/or public agencies at the central government level (upper horizontally); ii) between different layers of government at the local, regional, provincial/state, national and supranational levels 
(vertically); and iii) across different actors at the sub-national level (lower horizontally) (OECD, 2011).

Furthermore, we distinguish scale from level as per Daniell \& Barreteau (2014) where scale is the relative size or extent of something (Oxford Dictionary, 2017) and levels are a graduated range within each scale. According to this definition, the temporal scale for example may include the levels of hours, days, weeks, years, centuries, etc. Daniell \& Barreteau (2014) therefore distinguish multi-level from cross-scale interactions. The former includes interactions which take place within a single scale while the latter includes interactions which take place from one scale to another. We will focus in this article on multi-level governance. In the governance literature, interactions among multiple levels are commonly linked to polycentric or adaptive governance (Marshall, 2007; Ostrom, 1999; Pahl-Wostl, 2015) and multi-level governance (Bache \& Flinders, 2004; Hooghe \& Marks, 2004). Polycentric governance typically looks into the balance between bottom-up and top-down influences and the capacity of actors to self-organise (Huntjens, Pahl-Wostl, \& Grin, 2010; Pahl-Wostl \& Knieper, 2014).

Ferrand, Daniell, Popova, Ribarova, \& Coad (2010) identify five typical shapes of participation in multi-level processes (figure 1). Each shape shows the extent to which stakeholders are involved at each level. Shape 1 for instance may correspond to a direct vote by citizens on a proposal made by the national government. Shape 2 may correspond to a decentralised process in which regional governments involve communities and individuals in line with national directives. Shape 3 may correspond to a process handled at the regional level but with a will to involve upper and lower levels. Transnational and individual levels are only partially involved. Shape 4 may correspond to a process including only regional and community representatives. Finally, shape 5 may correspond to a regional initiative partially involving the lower community level. Non-governmental organisations, businesses and scientific experts may be engaged at many levels. Although this representation has limitations (e.g. it does not specify the nature of the engagement of stakeholders at each level), we argue that it provides a good basis for visualising which levels are engaged in a specific governance process and therefore which interactions may be sought. 


\section{Transnational \\ National / State \\ Regional \\ Community Individuals}

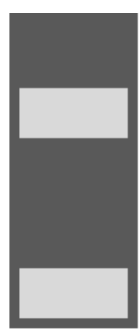

1

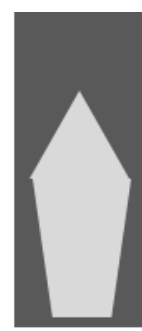

2

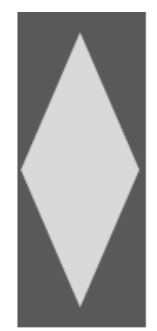

3

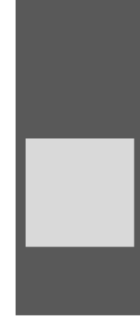

4

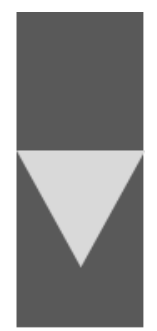

5

Figure 1. Typical shapes of participation in multi-level processes (Source: adapted from Ferrand et al., 2010)

A number of studies analyse ways of fostering interactions among multiple levels of water governance. Cash et al. (2006) for instance list three responses to foster multilevel governance:

- institutional interplay: interaction among government agencies, international organizations, and local community based resource users,

- co-management: power and responsibility sharing between governments/managing authorities and communities, and

- boundary or bridging organisations: groups that play an intermediary role between different arenas, levels, or scales and facilitate knowledge and information exchange.

The OECD lists a number of governance instruments for co-ordinating water policies at horizontal and vertical levels (OECD, 2011). Example of instruments for horizontal coordination include multi-sectoral conferences, co-ordination groups of experts, inter-agency programmes, inter-ministerial bodies or commissions, ad hoc high-level structures, central agencies and line ministries with specific water prerogatives. Example of instruments for vertical coordination include, among others, water agencies or river basin organisations, regulations for sharing roles between levels of government, co-ordination agencies or commissions, contractual arrangements, financial transfers and shared databases. A number of other frameworks have been developed which could be used to describe these multi-dimensional interactions (e.g. Geels \& Schot, 2007; Lovell et al., 2002; Lubell, 2013; Pahl-Wostl, 2015). These frameworks are very useful and they all promote participation as a way to foster interactions across multiple levels of water governance. However, we argue that beyond building the case for stakeholder engagement, they do not always concretely explain 
how to achieve a middle ground, that is, how to implement multi-level participatory water governance on the ground as one way to achieve greater efficiency in water management.

But implementing multi-level participatory governance is not that easy. The OECD (2011) has identified seven multi-level governance gaps: administrative, information, policy, capacity, funding, objective and accountability. Other authors also list issues and challenges related to scale and/or levels. Cash et al. (2006) identify three scale challenges: ignorance, mismatch and plurality. Ignorance corresponds to the failure to recognize the complexity linked to cross-level and cross-scale interactions. Mismatches are an incongruence between biophysical systems and governance systems, such as when boundaries of administrative jurisdictions do not relate to the areal extent of ecosystems (Young, 2008). Plurality is the failure to recognize heterogeneity in the way that scales are perceived and valued by different actors, even at the same level (Cash et al., 2006 p.4). Lovell, Mandondo, \& Moriarty (2002) identify scaling issues related to time, space, institutions, and environments.

The key question, when it comes to multi-level water governance and stakeholder engagement, lies in the extent to which stakeholders are involved in decision-making. This raises questions such as: who is engaged? When? How? How are decisions stemming from the stakeholder engagement process incorporated in policy-making? Researchers and water managers increasingly advocate for a wide engagement of stakeholders at various levels. They argue that such engagement is required to face future water challenges brought by global changes. This is advocated by authors promoting a shift from government to governance (e.g. Bache \& Flinders, 2004; Kluvankova-Oravska, Chobotova, Banaszak, Slavikova, \& Trifunovova, 2009). But how does one reach a middle ground and bridge formal (i.e. government-led) and informal (i.e. bottom-up) engagement processes?

\section{Methodology}

\section{Analytical framework: the OECD Stakeholder Engagement Checklist}


Author-produced version of the article published in International Journal of Water Resources Development, 2018, 35(3), p. 525-542. The original publication is available at https://www.tandfonline.com/doi/full/10.1080/07900627.2018.1452722

Doi: $10.1080 / 07900627.2018 .1452722$

We have therefore decided to use the OECD Stakeholder Engagement Checklist proposed in the OECD study Stakeholder Engagement for Inclusive Water Governance (figure A2; OECD, 2015) as the analytical framework and common reading template for our four case studies. The Checklist calls for a careful balance between what engagement tries to achieve, the resources it requires and whether it succeeds in reaching the intended objectives. Although engagement processes cannot be easily replicated from one context to another, the OECD Checklist is structured around six framework conditions needed for engagement processes to be relevant. Although these framework conditions are complementary to one another, we have chosen in this article to focus on the fifth one on Institutionalisation, structuring and integration. Given that our analysis focuses on institutionalised and emerging water-related stakeholder engagement, this fifth framework condition appeared as the most relevant for our analysis. However it must be noted that all conditions are equally important.

\section{INCLUSIVENESS \& EQUITY. Map all stakeholders who have a stake in the outcome or that are likely to be affected, as well as their responsibility, core motivations and interactions \\ 2. CLARITY OF GOALS, TRANSPARENCY \\ \& ACCOUNTABILITY. Define the ultimate line of decision rnaking, the objectives of stakeholder engagement and the expected use of inputs \\ 3. CAPACITY \& INFORMATION. Allocate proper financial and hur a resources and share needed information for result-oriented stakeholder engagement \\ NECESSARY CONDITIONS FOR STAKEHOLDER ENGAGEMENT IN WATER GOVERNANCE \\ 4. EFFICIENCY \& EFFECTIVENESS. Regularly assess the process and outcomes of stakeholder engagement to learn, adjust and improve accordingly}

\section{INSTITUTIONALISATION, STRUCTURING \& INTEGRATION. Embed}

engagement processes in clear legal and policy frameworks, organisational structures/principles and responsible authorities

\section{ADAPTIVENESS. Customise the type and level of}

engagement as needed and keep the process flexible to changing circumstances 
Author-produced version of the article published in International Journal of Water Resources Development, 2018, 35(3), p. 525-542. The original publication is available at https://www.tandfonline.com/doi/full/10.1080/07900627.2018.1452722

Doi: $10.1080 / 07900627.2018 .1452722$

Figure A2. Framework conditions for stakeholder engagement in water governance (Source: OECD, 2015)

Institutionalisation, structuring and integration: Embed engagement processes in clear legal and policy frameworks, organisational structures/principles and responsible authorities

a Requirements for stakeholder engagement are in place within the organisation. Binding and non-binding requirements have the potential to boost stakeholder engagement in the water sector, while triggering policy change. They help set standards for inclusive decision making and the capacity to assess the compliance of decision making with these requirements.

b Establishment of standing stakeholder advisory group at the appropriate level of government that reflects the broadest range of interests possible and with an equal number of seats across categories of stakeholders. Advisory groups help ensure that all stakeholders are properly involved throughout the water policy/project process, while finding the right balance between inclusiveness and empowerment of stakeholders. They can also be safeguards against consultation capture as well as prejudice to a particular category of stakeholders.

c Definition of explicit, fair and balanced ground rules for engagement within water policy process goals. Clarifying the goals for engagement is key to building mutual understanding and trust of how stakeholders may be involved in the process, and for informed stakeholders to provide quality contributions in line with expectations. It also helps ensure transparency and accountability in how the engagement process is designed and implemented, and thus improve credibility and legitimacy.

d Charters and the rules of the game are clearly established. Charters or clear operating rules are critical to move from reactive to proactive and systematic stakeholder engagement in the water sector. Such rules should include what is expected of stakeholders, the types of decisionmaking processes that should be applied, at which stage of the decision-making process the engagement duty should apply, what information should be provided to stakeholders and how, who should be involved, the targeted outcomes.

e A business case has been developed to support stakeholder engagement. A business case for inclusive decision making and policy or project implementation, and for engaging further with stakeholders, can help to move towards engagement processes that deliver their full potential for meeting water challenges, and to encourage decision-makers to invest more in stakeholder engagement.

f Reporting on the compliance with existing requirements is in place. Regularly assessing whether stakeholder engagement processes meet their requirements can help to learn, adjust and improve accordingly. Structuring and institutionalising engagement processes should not prevent these processes from being flexible and adaptive to take into consideration what works and what could be done better.

Table 1. Checklist for the fifth framework condition for stakeholder engagement in water governance on institutionalisation, structuring and integration (Source: OECD, 2015)

\section{Data collection and analysis}

The case studies on the Netherlands and the United-States were submitted on a voluntary basis in the framework of the OECD study Stakeholder Engagement for Inclusive Water Governance, respectively by the Delta Programme team 
(https://www.government.nl/topics/delta-programme) and the Environmental Protection Agency (https://www.epa.gov). They were collected as part of a broad call for case studies of specific stakeholder engagement initiatives on water management extended in June 2014. In all, 69 case studies were collected and presented in the OECD study to illustrate the evidence-based assessment and policy recommendations. More specifically, case study providers were required to fill-in a template aiming to collect data on the main characteristics of the case study (i.e. the overall objective, the type of stakeholders involved, the engagement mechanisms employed, the sources of funding, etc.); the evaluation (i.e. tangible benefits, costs incurred, challenges, outcomes, etc.); and lessons learned and replicability (i.e. enabling factors, replication potential, etc.).

Since the Ugandan and Ethiopian participatory processes were developed as part of the AfroMaison research project, data for the analysis of these two cases was collected through a regular monitoring and evaluation of the stakeholder engagement processes carried out by local and international researchers and key participants. Methods used for monitoring and evaluation included a logbook (Etienne, 2011), attendance lists, participants' expectations, pictures, videos, participant observation, questionnaires and interviews of facilitators, participants and non-participants. For a complete description of the participatory planning process and monitoring and evaluation protocol, see Ducrot et al. (2014), Hassenforder et al. (2016a) and Hassenforder et al. (2016b).

Analysis of the Netherlands and the United-States cases was conducted by the two OECD authors who collected the templates and carried out the initial study Stakeholder Engagement for Inclusive Water Governance. Analysis of the Ugandan and Ethiopian cases was done by the two IRSTEA authors who were involved in the monitoring of the participatory processes. Transcripts were qualitatively analysed to identify the presence of the six variables, or codes, listed in the Checklist. All the data which did not correspond to any of these variables was assigned a new code, corresponding to surprises. Coding was therefore made following both an inductive and a deductive process (Fereday \& Muir-Cochrane, 2006). Data collected through attendance lists and Likert scale items in the questionnaires in Uganda and Ethiopia was analysed quantitatively. 


\section{Analysis of the case studies}

\section{Experiences in formal stakeholder engagement: The Delta Programme (Netherlands) and the Chesapeake Bay Program (United States)}

The Netherlands has a strong history of living with too much water. Since the $13^{\text {th }}$ century, Dutch water governance successfully reclaimed land from the sea and kept the territory dry through the development of a sophisticated system of flood defences. This performance has relied extensively on regional water authorities (or water boards), centuries-old, flexible and evolving institutions that have developed world-class engineering and on-the-ground engagement with stakeholders (the Polder Model), while playing a central role both as proactive water managers and as platforms to engage water users (Havekes et al., 2004; Lazaroms and Poos, 2004, OECD, 2014). This participatory approach corresponds to shape 4 in figure 1 where participation takes a square shape involving both the regional and community levels. However, this longstanding approach is put into question by two rising trends. First, the traditional infrastructural and defensive responses to major floods has been challenged by a new paradigm to make room for the river (Edelenbos et al. 2013), combining innovative architecture, urbanisation and landscape solutions to build with nature and live with water. Second, the Polder Model, rooted in history and based on centuries-old civic culture does not cover the full range of water issues, and flood protection standards, for instance they remain largely absent from discussions or are void in leading to effective decision making. This can be explained by a high level of trust in government and the successful avoidance of major flood disasters since 1953 (OECD, 2014). The search for a new adaptive and participatory perspective on water security partly motivated the development of the Delta Programme as a national planning instrument launched in 2010 to address two priority goals: protect the Netherlands against flooding and ensure freshwater supply (Delta Programme Commissioner, 2011). It is a joint endeavour between the central government, the provinces, municipal councils and regional water authorities, in close co-operation with social organisations and businesses. In many ways, the Delta Programme is an attempt at building a common understanding of waterrelated risks in the Netherlands, where there is a striking awareness gap among Dutch 
citizens related to water risks. Many people are not aware of the basics about evacuation policy or that their property is built on a flood plain (OECD, 2014).

The Chesapeake Bay watershed on the east coast of the United States is considered a national treasure and resource of worldwide significance (Chesapeake Bay Restoration Act of 2000). It is also the largest estuary in the United States and one of the largest and most productive in the world. The Chesapeake Bay Foundation (http://www.cbf.org) has estimated that the Chesapeake Bay area provides more than US\$107 billion in ecosystem services, such as flood and hurricane protection, air and water purification, and food production every year (Chesapeake Bay Foundation, 2012). However, the Chesapeake Bay watershed has suffered from toxic pollution, excess nutrients and sediment for decades. In particular, diffuse pollution from agriculture has been largely unregulated and remains a significant contributor to water quality impairments not only in the Chesapeake Bay watershed, but across the country. In the late 1970s and early 1980s, the United States Congress funded scientific and estuarine research of the Chesapeake Bay, which pinpointed three areas that required immediate attention: i) toxic pollution, ii) nutrient over-enrichment and iii) dwindling underwater bay grasses. In 1983, the governors of Maryland, Virginia and Pennsylvania; the mayor of the District of Columbia; and the administrator of the United States Environmental Protection Agency (EPA) formed the Chesapeake Bay Program (http://www.chesapeakebay.net), building on their common recognition of citizen awareness for environmental protection in that area. To date, the Program remains one of the earliest examples of multi-level partnership between state, federal, academic and local watershed organisations in the United States to build and adopt policies that support water and ecosystem restoration (i.e. mimicking shape 2 of figure 1 involving all levels from national to individual).

In both the Dutch and Chesapeake Bay cases, engagement processes are embedded in national legislation (item [a] on requirements for stakeholder engagement within the organisation of the Checklist). The Delta Act on Flood Risk Management and Freshwater Supplies (Dutch House of Representatives, 2012) that came into effect in January 2012 as an amendment to the Water Act is the backbone of the Delta Programme (Ministry of Transport, Public Works and Water Management, 2010). It mandates the Delta Commissioner, appointed by the government, to lead the Delta 
Programme in consultation with the relevant authorities and stakeholders. In the United States, the Chesapeake Bay Program operates according to the 1983 Chesapeake Bay Agreement (106 ${ }^{\text {th }}$ Congress of the United States, 2000) under the supervision of the US Environmental Protection Agency (EPA) according to National and Interstate agreements, with the objective to reduce the amount of nutrients entering the Chesapeake Bay - primarily nitrogen and phosphorus.

Both cases benefit from dedicated financial resources to legally guarantee budgets to cover the costs of planned measures and related activities on stakeholder engagement. The Delta Act establishes the Delta Fund, separate from the Infrastructure Fund, which ensures that sufficient financial resources are dedicated to effectively implementing the objectives of the Delta Programme (Delta Programme Commissioner, 2011). Similarly, the Chesapeake Bay Agreement contains ten goals to advance the restoration and protection of the Bay watershed with clear sets of outcomes and time-bound and measurable targets. It is funded by the US Congress, the EPA and State-level agencies.

In the Netherlands, advocacy groups and the business community are informed and aware of the content and underlying processes of political decisions and projects, and have access to data, studies and climate-change scenarios. They are closely consulted and involved through multi-stakeholder dialogues for the formulation of the National and local water plans (item [b] on the establishment of standing stakeholder advisory group at the appropriate level of government that reflects the broadest range of interests possible and with an equal number of seats across categories of stakeholders). The Delta Act clarifies the modalities of when and how to engage stakeholders (items [c] on the definition of explicit, fair and balanced ground rules for engagement within water policy process goals and [d] on the establishment of charters and the rules of the game). A Steering Group that comprises representatives from the government as well as subnational and non-state actors provides strategic guidance throughout the implementation of the Delta Programme. Stakeholders are also engaged as part of joint fact-finding efforts that consist in upstream consultation to define and choose solutions for tackling water challenges, review measures proposed by the government, and provide feedback, particularly through information-sharing and awareness-raising activities. The Delta Programme makes use of scientific and technical expertise to design and implement projects. 
In the Chesapeake Bay case, an advisory group was created to specifically represent residents and stakeholders of the Chesapeake Bay watershed. This Citizens Advisory Committee (http://www.chesapeakebay.net/groups/group/citizens_advisory_committee) advises the Program on all restoration aspects and members of the Committee communicate with their constituencies to increase understanding. The Chesapeake Bay Program includes other modalities to involve stakeholders. The Program comprises a number of committees, goal implementation teams, workshops and actions teams through which stakeholders can get involved. They work according to agreements that set out clear outcomes and time-bound and measurable targets to contribute to achieving restoration and protection of the bay watershed (items [c] and [d]). In addition, the ChesapeakeStat website helps to foster co-ordination among partners and improve government accountability. Stewardship funding was also set up and has been used to educate citizens on restoration, provide outreach and build capacity.

In both cases, engagement efforts are monitored and assessed. The Delta Act requires the formulation of annual reports to provide an overview of all measures taken for the implementation of the Delta Programme, including on stakeholder engagement (item [f] on reporting on the compliance with existing requirements). Such evaluations, through in-depth interviews and surveys of stakeholders involved, have helped identify how the programme could be more effectively organised, and recommendations to strengthen the Delta Programme have been formulated and shared with the Delta Commissioner. In the Chesapeake Bay, monitoring and reporting of meetings, actionable items and public hearings all serve to effectively implement the Program and maintain smooth management (item [f]). In addition, each of the seven Bay watershed jurisdictions will create a watershed implementation plan that documents how they partner with stakeholders to achieve and maintain water quality standards. Information sharing and conflict resolution take place as part of these plans.

\section{Experiences in spontaneous stakeholder engagement: The Rwenzori region}

\section{Mpanga river management plan (Uganda) and the Gumera catchment management plan (Ethiopia)}

Both cases used the same participatory planning approach, adapted from the Aquastress project (AquaStress 2005-2008, Ferrand et al. 2006). The project delivered 
interdisciplinary methodologies enabling actors at different levels of involvement and at different stages of the planning process to mitigate water stress problems (Aquastress, 2017). The participatory planning approach adapted from this project and implemented in the Rwenzori region and Gumera catchment included six phases (Hassenforder, 2015):

1. Procedural agreement: facilitators and key stakeholders engineer and validate the participatory process to fit the local context.

2. Identification of the focal issue: participants discuss on a common long-term objective and elicit their points of view, values and preferences.

3. Proposal of actions: participants brainstorm on potential actions likely to address the focal issue. Resources needed and expected impacts of each action are specified and discussed using a generic action template. Experts also suggest actions which are set forth for approval by participants.

4. Selection and organisation of actions in time, space and at organisational levels using the COOPLAN (COOperative PLANning) matrix (Ferrand, Hassenforder, Abrami, \& Aquae-Gaudi, 2015). Based on available resources and expected impacts, participants discuss about the feasibility, coherence and efficiency of the resulting water management plan.

5. Test of the plan using a role-playing game (based on Wat-A-Game toolkit; Abrami et al. 2012; Ferrand et al. 2009) developed concomitantly by facilitators and researchers with multiple inputs from participants. Actions from the plan are translated into action cards in the role-playing game allowing participants to explore the social and environmental impacts of these actions and to possibly suggest new ones. The plan and game are readjusted on the way.

6. Agreement among participants on plan implementation: who will do what, when, where and with what resources.

In Ethiopia, the participatory plan developed by participants through the six-steps approach detailed above focused on reducing soil erosion by stopping free grazing; while in Uganda, the focal issue aimed at addressing land degradation, poverty, water pollution, deforestation and population increase. The participatory planning approach was implemented in both cases with a group of meso-level stakeholders. The meso level is defined as the intermediary level between community level and national level. In Uganda, meso-level workshops were facilitated by six local researchers from Mountains 
of the Moon community University (MMU) in Fort Portal, supplemented by French researchers from the AfroMaison project. The four workshops of the meso-level process involved 29 to 68 participants. In Ethiopia, the facilitators who engineered, implemented and managed the participatory process were eleven researchers, from international research institutes based in Addis Ababa and France . Each of the three workshops that took place in the Ethiopian process engaged 38 to 52 participants (Hassenforder, 2015).

In Uganda, the planning process was spontaneously extended at various levels starting at the meso level, down to the local level and up to the national level. This corresponds to shape 2 in figure 1 where all levels from national to individual are involved and where the meso, or regional, level is more largely involved than others. This extension is spontaneous in the sense that it was not originally planned in AfroMaison. The participatory planning process was originally meant to be implemented at the meso level only. However, Ugandan facilitators were enthusiastic towards the process, and the role-playing game in particular, and therefore decided to set up a partnership with the Sustainable Agricultural Trainers Network (SATNET) in order to implement the participatory planning approach at the local level, in 35 communities throughout the Rwenzori region. Community process facilitators (CPFs) who are part of SATNET facilitated the local level workshops. Each local group included an average of 17 participants. Among local participants, $46 \%$ were women, $38 \%$ were men and $17 \%$ were children. The vast majority were farmers and pastoralists (Hassenforder, 2015).

At the national level, facilitators of the process attempted to uplevel the process and to embed it into more formal or institutionalised stakeholder engagement. Two meetings were planned with the Minister of Water and Environment in 2013 but were cancelled by the Minister. For the two meso level meetings, in January and July 2013, invitations were sent to three members of the national parliament representing the Rwenzori region. One attended (Hassenforder, 2015). The same person later joined facilitators at the final AfroMaison event in Brussels in May 2014 where he outlined his will to implementing the plan. He also committed to convening a meeting with the parliament environment committee (Hassenforder, 2015). In Ethiopia, the process was only implemented at the regional level but in parallel between a group of decision-makers and a group of farmers 
(shape 4 in figure 1 where participation takes a square shape involving both the regional and community levels; Hassenforder, Barreteau, Daniell, Pittock, \& Ferrand, 2015). This aimed partly at compensating power differences among participants and at fostering regional decision-makers to adopt an open posture favourable to stakeholder engagement. A detailed description of the participatory process in both case studies is provided in Hassenforder (2015).

In the Rwenzori case, no real requirement for stakeholder engagement existed within Mountains of the Moon University, which was the organisation leading the Ugandan stakeholder engagement process (item [a] of the Checklist). Some requirements for stakeholder engagement exist at the national level, which were mostly developed through decentralisation policies, but interviews revealed that they are often not implemented and considered by stakeholders as unsatisfactory. Indeed, from 1992, natural resources management (NRM) in Uganda was devolved to local governments (Onyach-Olaa, 2003), shaped by a five-tier structure (district/county/subcounty/parish/village). Environment committees and officers are responsible for community engagement and implementation of NRM laws. However, lack of governmental funds, heavy workloads and corruption impede adequate implementation of this legal framework (Hassenforder, Ferrand, Pittock, Daniell, \& Barreteau, 2015b).

In Fogera, facilitators of the stakeholder engagement process belonged to international research institutes which regularly implemented participatory processes in the region. However, no formal requirement for stakeholder engagement existed, some processes were therefore still developed. At the national level, a decentralized system is also in place (four-tier decentralized system -regions/zones/woredas/kebeles or peasant associations - and development agents). Stakeholder engagement is generally limited to mass awareness-raising and training campaigns destined to farming communities to increase food security by intensifying agricultural productivity (Hassenforder, 2015).

In both the Ugandan and Ethiopian cases, the participatory processes were supported by a group of individuals with a close connection to facilitators. This group was composed of different categories of stakeholders and its objective was to provide strategic advice on the process (item [b]). For instance, they tested initial versions of the role-playing game models to make them representative of the reality and adapt their 
degree of complexity to the participants. To a certain extent, the participants' group itself could be considered as an advisory group since they were the leaders of their own process. They reflected the broadest range of interests possible and tried to the extent possible to have an equal number of seats across categories of stakeholders, including government representatives.

In both cases, the engagement process was framed by researchers and local stakeholders who ensured that ground rules for engagement and rules of the game were made transparent, explicit, fair and balanced (items [c] and [d]). Ground rules for engagement included an explanation of how participants were selected, why they were there (the objectives), what was expected from each meeting (the expected outcomes), the various steps, the role of the various stakeholders in the process, how decisions were being made, the rules and mechanisms, the interactions among participants (who will interact with whom and how) and the monitoring and evaluation (objectives, methods and feedback). In addition, facilitators monitored the various workshops and had to assess after each event whether these rules had been explicitly stated to participants.

In Ethiopia, the various participatory activities developed by researchers and development organisations on the ground served as business cases to support stakeholder engagement (item [e]). Notably, participatory innovation platforms had been developed at three levels, including a national one (CGIAR, 2015). Observation of the process and interviews showed that these cases had an impact on some decisionmakers who started to support the need for stakeholder engagement in water policies. In Uganda, no business case was used since no comparable initiative existed in the region. Exchanges with stakeholders from the three other AfroMaison cases (Mali, Tunisia and South Africa), however, provided opportunities to discover other stakeholder engagement processes and their inherent drivers and constraints.

In both cases, a systematic monitoring and evaluation of the stakeholder engagement process was implemented as part of the research project (item [f]). The monitoring and evaluation methods used are detailed in the data collection and analysis section (and in Hassenforder et al. 2016a). 
In addition to the elements revealed by the checklist, analysis of these two cases revealed some key lessons for the institutionalisation of stakeholder engagement processes. In Uganda, facilitators tried upleveling the process to the national level, but were largely unsuccessful. We suggest that for the institutionalisation of a bottom up engagement process, upleveling processes to the national level may not be relevant at the beginning of the participatory process. Instead, one or two key national stakeholders can be involved to legitimate the meso and local processes. This is also less resource intensive: attempts to uplevel the process to the national level can require frequent trips to the capital which can be long and costly. These national stakeholders may be members of parliament or ministry staff who have an influential position and feel committed because they originate from the region or are concerned by NRM. Their participation in key workshops may favour attendance by meso-level decision makers and legitimate the process (Hassenforder, 2015). In Ethiopia, a similar strategy was applied through innovation platforms developed at three levels, including a national one (CGIAR, 2015). It is then likely that gradually, development of the meso and local level processes, as well as involvement of a few key national players, could foster wider involvement and change at higher levels (Folke, Hahn, Olsson, \& Norberg, 2005).

\section{Discussions and Conclusions}

The objective of this article was to analyse the strategies used in formal (i.e. government-led) and informal (i.e. bottom-up) engagement processes in search of a middle ground between institutionalised and emerging water-related stakeholder engagement processes. This article did not aim at providing normative recommendations on how stakeholder engagement in water governance should be carried out. In some cases, institutional stakeholder engagement processes seeking to engage local level stakeholders may be more adequate than emergent stakeholder engagement processes seeking institutionalisation, or vice-versa. This depends on the territory under consideration - a river basin, an irrigated system, an aquifer -, on the stakeholders concerned, on existing institutional arrangements and on a number of other factors. This being said, this article is based on the assumption that multi-level participatory water governance, in territories where stakeholders have a stake in multiple levels, is necessary. Adaptive and integrated multi-level water governance 
cannot take place without the engagement of stakeholders. Water governance and management rely on stakeholders to provide local knowledge on a given river basin, take decisions, make proposals or implement strategies. It is therefore essential for these stakeholders to be able to share their knowledge and representations and to increase their capacities to build common water management strategies while having a holistic vision of the social-environmental system under consideration.

Hence a middle ground between institutionalised and emerging water-related stakeholder engagement processes can be beneficial. It can be an alternative governance process where bureaucratic and top-down water governance is challenged (Susskind, 2013). How this middle ground is shaped may differ from one place to another, depending on the stakeholders facilitating the process, the extent to which the process reaches other levels and the nature of cross-level interactions created. Hence, depending on the social-environmental system under consideration, the search for this middle ground may need to emphasize different elements. The analysis of the four case studies presented in this article illustrates this.

The Dutch and United-States case studies illustrate how institutionalised forms of engagement processes can benefit from a strong leadership commitment. The support of political champions, at various levels of government has translated into dedicated funding (namely the Delta Fund in the Netherlands and State funding in the United States) to sustain these engagement processes, amongst other resources. In both the Dutch and United-States cases, legal requirements for stakeholder engagement have also meant a clear allocation of responsibilities across the stakeholders involved, as well as milestones and reporting obligations to keep those involved accountable. Formal engagement processes can also yield broader policy benefits, particularly in terms of efficiency. The co-ordination of multi-level partnerships, as provided by the Delta Programme and the Chesapeake Bay Program, is a powerful tool to prevent segmented working methods and scattered responsibilities between the different levels of government. Co-operation among actors at various levels, collectively agreed-upon objectives, and jointly designed projects for the implementation of these two programmes are important mechanisms that align priorities across policy areas and political agendas, and allow for continuity of public policy at sub-national levels. The consultation of advocacy groups, academics and the business community also ensures 
all motivations are aligned. In addition, it contributes to knowledge production and capacity building. The Delta Programme makes use of scientific and technical expertise to design and implement projects. Universities, knowledge institutes and implementation agencies are closely involved and help diagnose knowledge gaps. In turn, they participate in developing knowledge agendas and strategies, in close cooperation with the responsible governments, to target specific qualification needs and help bridge the capacity gap.

However, insights from the Dutch and United States case studies as well as OECD work on stakeholder engagement in water governance show that structured and structural engagement processes are also fraught with challenges and shortcomings. First, to be effective, institutionalised forms of engagement implies securing the needed financial and human resources at the appropriate levels to sustain the engagement process. Second, formalising, or even institutionalising collective decision-making related to water issues requires strong leadership commitment with clear objectives and strategies to prevent and manage risks of capture. Third, the shift to more formal processes have also led, at times, to a saturated engagement landscape whereby a growing number of water issues are subject to stakeholder engagement leading to consultation fatigue. Stakeholders have limited resources to get involved and have difficulties keeping up with the high level of engagement asked of them. Finally, legal requirements and frameworks for stakeholder engagement do not always lead to optimal and quality outcomes. When they require some form of engagement, without a clear mandate on the exact form and the matter concerned, it can cultivate a tick-the-box mentality promoting the minimum level of engagement required (e.g. information sharing) without taking the maximum benefit from it.

Informal forms of engagement processes tend to rely more on champions such as facilitators and groups of individuals having a close connection to these champions (close friends) who provide strategic advice on the process. In particular, the legitimacy and social relationships of these actors with participants are key. In parallel, the fact that the Ugandan and Ethiopian processes were framed by researchers and experts of engagement ensured that ground rules, charters and rules of the game were clearly established and that processes were closely monitored and evaluated. This might not be the case in engagement processes that are fully self-organised. These informal forms of 
engagement processes are highly place-based and fit-to-purpose since they emerge to answer specific needs and expectations. There are also often more flexible and adaptive than institutionalised forms of engagement processes. For instance, they might be more prone to swiftly address local emergencies (e.g. water pollutions, floods) and contingencies as compared to formal approaches that can be weighed down by bureaucracy and procedures. In parallel, informal forms of engagement processes may also have a weaker incentive to engage stakeholders, especially decision makers and may present a greater risk of capture if not embedded in a clear framework.

Beyond structural elements analysed through the OECD Stakeholder Engagement Checklist, the analysis carried out in this article shows that procedural elements traditionally highlighted by researchers and practitioners working on participation (e.g. IAP2, 2007; Rowe \& Frewer, 2000) such as representativeness, transparency, accountability and accessibility are essential for this middle ground. For instance, building the accountability of the stakeholder engagement process facilitator goes through the demonstration of its capacity to frame the process, to engage stakeholders (including at other levels) and to produce results, as was the case with the ChesapeakeStat website. It appears that the emphasis was put on different elements in each case study to reach a middle ground but that some elements are transversal to all four cases. This includes for instance the importance of facilitators and advisory groups or the room for manoeuvre left to stakeholders in the policy making process. These transversal elements may however be impacted by contextual elements such as power inequalities (see e.g. Cullen, Tucker, Snyder, Lema, \& Duncan, 2014), diverging interests (Poolman \& van de Giesen, 2006), socio-political events or other sectoral policies (Varis, Enckell, \& Keskinen, 2014). These elements need to be taken into account, hence the importance of research, monitoring and evaluation of participatory processes and their strategies to reach a middle ground.

Moving forward, our hypothesis is that one way to make the two approaches converge lies in assessing the effectiveness and efficiency of practical cases, in different regions and at different levels. To provide an incentive for collaboration, future work and research should strive to monitor and evaluate formal and informal engagement processes and shed light on their contribution to adequate water governance. Such monitoring and evaluation protocols should not serve reporting purposes only, but 
concretely support decision-making. They can only provide information on who is engaged, when and how, and provide evidence on the contribution of engagement processes to adequate water governance and socio-environmental change. A promising avenue towards this is the realisation of the Sustainable Development Goals adopted in 2015. A specific goal dedicated to water includes a target focusing on supporting and strengthening the participation of local communities in improving water and sanitation management (goal 6.b). As such, it provides a strong and universal incentive to move the stakeholder engagement agenda forward, building both on formal and informal approaches. But experiences such as the Dutch, Chesapeake Bay (United States), Ugandan and Ethiopian cases show that the middle ground between bottom up and top down participation, should it be achieved, corresponds to a complex reality which cannot be analysed solely by quantitative indicators such as the proportion of local administrative units with established and operational policies and procedures for participation of local communities in water and sanitation management. Yet this quantitative indicator is the official indicator that was retained to monitor Sustainable Development Goal 6.b (IAEG-SDGs, 2016). This article highlights the need for a sound, coherent and mixed (i.e. both quantitative and qualitative) monitoring and evaluation of formal and informal stakeholder engagement processes. This aim deserves the joint attention of both policy-makers and researchers in order to achieve a middle ground between institutionalised and emerging water-related stakeholder engagement processes for sound water governance.

\section{Acknowledgements}

The authors thank the editors of the International Journal of Water Resources Development for editing this special issue on Understanding emergent participation practices in water governance. Engagement, participation and inclusiveness are key aspects of water governance and such a special issue helps give them the credit they deserve. The authors also thank all the people who contributed to collecting data on the four case studies, especially the teams from the Dutch Delta Programme, the United States Environmental Protection Agency, Mountains of the Moon University, The Sustainable Agricultural Trainers Network, the International Water Management 
Institute and the International Livestock Research Institute. Thanks also go to Erika Ferrand Cooper for proof-reading the article.

\section{References}

$106^{\text {th }}$ Congress of the United States (2000), Chesapeake Bay Restoration Act, https://www.congress.gov/bill/106th-congress/house-bill/3039 (last consulted on 26 June 2017).

Abrami, G., Ferrand, N., Morardet, S., Murgue, C., Popova, A., De Fooij, H., AquaeGaudi, W. (2012). Wat-A-Game, a toolkit for building role-playing games about integrated water management. In R. Seppelt, A. A. Voinov, S. Lange, \& D. Bankamp (Eds.), iEMSs Sixth Biennial Meeting. Leipzig, Germany. Retrieved from http://www.iemss.org/society/index.php/iemss-2012-proceedings

AfroMaison project (2011-2014), 'Africa at a meso-scale: Adaptive and integrated tools and strategies for natural resources management' funded by the 7th Framework Program of the European Union, theme 'ENV.2010.2.1.1-1' [Integrated management of water and other natural resources in Africa]

AquaStress Integrated Project (2005-2008), "Mitigation of WaterStress through new approaches to Integrating management, technical, economic and institutional instruments" funded by the 6th Framework Program of the European Union, Priority 1.1.6.3 [Global Change and Ecosystems]

Aquastress website welcome page, http://www.aquastress.net/ consulted on $08^{\text {th }}$ June 2017

Arnstein, S.R. (1969), A ladder of citizen participation. J. Am. Inst. Plan., 35, 216-224.

Bache, I., \& Flinders, M. (2004). Multi-level Governance. (I. Bache \& M. Flinders, Eds.). Oxford: Oxford University Press.

Brown, M.; Wyckoff-Baird, B. (1992), Designing Integrated Conservation and Development Projects; Biodiversity Support Program: Washington, DC, USA.

Cash, D. W., Adger, W. N., Berkes, F., Garden, P., Lebel, L., Olsson, P., ... Young, O. (2006). Scale and cross-scale dynamics: governance and information in a multilevel world. Ecology and Society, 11(2), 8.

CGIAR. (2015). Nile Basin Development Challenge Wikispace - Innovation Platforms. Retrieved from http://nilebdc.wikispaces.com/innovationplatforms

Chesapeake Bay Foundation, (2012). The Economic Argument for Cleaning up the Chesapeake Bay and its Rivers. Available at cbf.org/economic report. 
Chesapeake Bay Programme (1983), The Chesapeake Bay Agreement of 1983, http://www.chesapeakebay.net/documents/1983_CB_Agreement2.pdf (last consulted on 26 June 2017).

Cohen, A., \& Davidson, S. (2011). The watershed approach: Challenges, antecedents, and the transition from technical tool to governance unit. Water Alternatives, 4(1), 1-14. Retrieved from www.water-alternatives.org/index.php/allabs/123-a4-1-1/file

Cullen, B., Tucker, J., Snyder, K., Lema, Z., \& Duncan, A. (2014). An analysis of power dynamics within innovation platforms for natural resource management. Innovation and Development, 4(2), 259-275. http://doi.org/10.1080/2157930X.2014.921274

Daniell, K. A., \& Barreteau, O. (2014). Water governance across competing scales: Coupling land and water management. Journal of Hydrology, 519(C), 2367-2380. http://doi.org/10.1016/j.jhydrol.2014.10.055

Daniell, K. A., Máñez Costa, M. A., Ferrand, N., Kingsborough, A. B., Coad, P., \& Ribarova, I. S. (2010). Aiding multi-level decision-making processes for climate change mitigation and adaptation. Regional Environmental Change, 11(2), 243-258. http://doi.org/10.1007/s10113-010-0162-0

Delaney, D., \& Leitner, H. (1997). The Political Construction of Scale. Polirical Geography, 16(2), 93-97.

Delta Programme Commission (2011), The 2011 Delta Programme, https://english.deltacommissaris.nl/deltaprogramme/documents/publications/2010/09/14/2011-delta-programme (last consulted on 26 June 2017).

Ducrot, R., Morardet, S., Hassenforder, E., Abrami, G., Johnston, R., D’Hayer, T., ... Ferrand, N. (2014). A process oriented approach to craft operational strategies for INRM at meso-scale - Operational strategies for adaptation and vulnerability reduction to global change D7.1. Draft version. Brussels, Belgium.

Dutch House of Representatives (2012), Delta Act on flood risk management and freshwater supplies, Parliamentary document 32 304, no. 25, https://english.deltacommissaris.nl/deltaprogramme/documents/publications/2012/09/18/delta-programme-2013 (last consulted on 26 June 2017).

Edelenbos, J., D. Roth and M. Winnubst (2013), "Dealing with uncertainties in the Dutch Room for the River programme: A comparison between the Overdiep polder and Noordwaard", in: Warner, J.F., A. van Buuren and J. Edelenbos (eds) (2012), Making Space for the River: Governance Experiences with Multifunctional River Flood Management in the US and Europe, IWA Publishing, London, pp. 51-62.

Etienne, M. (2011). Companion modelling A participatory approach to support sustainable development. (M. Etienne, Ed.). Versailles, France: Editions Quae.

European Parliament. (2000). Directive 2000/60/EC of the European Parliament and of the Council establishing a framework for the Community action in the field of water 
Author-produced version of the article published in International Journal of Water Resources Development, 2018, 35(3), p. 525-542. The original publication is available at https://www.tandfonline.com/doi/full/10.1080/07900627.2018.1452722

Doi: $10.1080 / 07900627.2018 .1452722$

policy. Brussels. Retrieved from http://eur-lex.europa.eu/legalcontent/EN/TXT/PDF/?uri=CELEX:02000L0060-20141120\&from=EN

Fereday, J., \& Muir-Cochrane, E. (2006). Demonstrating Rigor Using Thematic Analysis: A Hybrid Approach of Inductive and Deductive Coding and Theme Development. International Journal of Qualitative Methods, 5(1), 80-92.

Ferrand, N., Daniell, K. A., Popova, A., Ribarova, I. S., \& Coad, P. (2010). Multilevel Participatory modelling for integrated planning and water management. In Global Conference on Agricultural Research for Development - Workshop "A way to promote adaptive management of rural socio-ecological systems in multi-scale context: participatory modelling." Montpellier.

Ferrand, N., Farolfi, S., Abrami, G., \& Du Toit, D. (2009). WAT-A-GAME: sharing water and policies in your own basin. In "Learn to Game, Game to Learn", ISAGA 40th Annual Conference. Singapore.

Ferrand, N., Hare, M., \& Rougier, J.-E. (2006). Iskar Test Site Option Description Living with Flood and Drought. Methodological document to the Iskar Test Site, AquaStress IP, FP6, Europe. Brussels, Belgium.

Ferrand, N., Hassenforder, E., Abrami, G., \& Aquae-Gaudi, W. (2015). Integrated participatory modeling using the CoOPLAaGE toolkit. In Lamsade \& U. P. Dauphine (Eds.), International Workshop on Citizen Science. Paris. Retrieved from dimacs.rutgers.edu/Workshops/Citizen/Slides/EmelineHASSENFORDER.pdf

Fung, A. (2006), Varieties of participation in complex governance. Public Adm. Rev. 2006, 66, 66-75.

Garrido, S. (2014), Water Management, Spanish Irrigation Communities and Colonial Engineers, in Journal of Agrarian Change, Vol. 14 No. 3, July 2014, pp. 400-418.

Geels, F. W., \& Schot, J. (2007). Typology of sociotechnical transition pathways. Research Policy, 36, 399-417.

Gupta, J. (2008). Global change: analyzing scale and scaling in environmental governance. In O. R. Young, L. A. King, \& H. Schroeder (Eds.), Institutions and environmental change: Principal findings, applications, and research frontiers (pp. 225-258). MIT Press.

Habermas, J. (1986), The Structural Transformation of the Public Sphere: An Inquiry into a Category of Bourgeois Society; The MIT Press: Cambridge, MA, USA.

Abrami, G., Ferrand, N., Morardet, S., Murgue, C., Popova, A., De Fooij, H., ... AquaeGaudi, W. (2012). Wat-A-Game, a toolkit for building role-playing games about integrated water management. In R. Seppelt, A. A. Voinov, S. Lange, \& D. Bankamp (Eds.), iEMSs Sixth Biennial Meeting. Leipzig, Germany. Retrieved from http://www.iemss.org/society/index.php/iemss-2012-proceedings

Bache, I., \& Flinders, M. (2004). Multi-level Governance. (I. Bache \& M. Flinders, Eds.). Oxford: Oxford University Press. 
Cash, D. W., Adger, W. N., Berkes, F., Garden, P., Lebel, L., Olsson, P., ... Young, O. (2006). Scale and cross-scale dynamics: governance and information in a multilevel world. Ecology and Society, 11(2), 8.

CGIAR. (2015). Nile Basin Development Challenge Wikispace - Innovation Platforms. Retrieved from http://nilebdc.wikispaces.com/innovationplatforms

Cullen, B., Tucker, J., Snyder, K., Lema, Z., \& Duncan, A. (2014). An analysis of power dynamics within innovation platforms for natural resource management. Innovation and Development, 4(2), 259-275. https://doi.org/10.1080/2157930X.2014.921274

Daniell, K. A., \& Barreteau, O. (2014). Water governance across competing scales: Coupling land and water management. Journal of Hydrology, 519(C), 2367-2380. https://doi.org/10.1016/j.jhydrol.2014.10.055

Ducrot, R., Morardet, S., Hassenforder, E., Abrami, G., Johnston, R., D’Hayer, T., ... Ferrand, N. (2014). A process oriented approach to craft operational strategies for INRM at meso-scale - Operational strategies for adaptation and vulnerability reduction to global change D7.1. Draft version. Brussels, Belgium.

Etienne, M. (2011). Companion modelling A participatory approach to support sustainable development. (M. Etienne, Ed.). Versailles, France: Editions Quae.

European Parliament. (2000). Directive 2000/60/EC of the European Parliament and of the Council establishing a framework for the Community action in the field of water policy. Brussels. Retrieved from http://eur-lex.europa.eu/legalcontent/EN/TXT/PDF/?uri=CELEX:02000L0060-20141120\&from=EN

Fereday, J., \& Muir-Cochrane, E. (2006). Demonstrating Rigor Using Thematic Analysis: A Hybrid Approach of Inductive and Deductive Coding and Theme Development. International Journal of Qualitative Methods, 5(1), 80-92.

Ferrand, N., Daniell, K. A., Popova, A., Ribarova, I. S., \& Coad, P. (2010). Multilevel Participatory modelling for integrated planning and water management. In Global Conference on Agricultural Research for Development - Workshop "A way to promote adaptive management of rural socio-ecological systems in multi-scale context: participatory modelling." Montpellier.

Ferrand, N., Farolfi, S., Abrami, G., \& Du Toit, D. (2009). WAT-A-GAME: sharing water and policies in your own basin. In "Learn to Game, Game to Learn", ISAGA 40th Annual Conference. Singapore.

Ferrand, N., Hare, M., \& Rougier, J.-E. (2006). Iskar Test Site Option Description Living with Flood and Drought. Methodological document to the Iskar Test Site, AquaStress IP, FP6, Europe. Brussels, Belgium.

Ferrand, N., Hassenforder, E., Abrami, G., \& Aquae-Gaudi, W. (2015). Integrated participatory modeling using the CoOPLAaGE toolkit. In Lamsade \& U. P. Dauphine (Eds.), International Workshop on Citizen Science. Paris. Retrieved from dimacs.rutgers.edu/Workshops/Citizen/Slides/EmelineHASSENFORDER.pdf

Folke, C., Hahn, T., Olsson, P., \& Norberg, J. (2005). Adaptive governance of SocialEcological Systems. Annual Review of Environment and Resources, 30(1), 441- 
Author-produced version of the article published in International Journal of Water Resources Development, 2018, 35(3), p. 525-542. The original publication is available at https://www.tandfonline.com/doi/full/10.1080/07900627.2018.1452722

Doi: $10.1080 / 07900627.2018 .1452722$

473. https://doi.org/10.1146/annurev.energy.30.050504.144511

Geels, F. W., \& Schot, J. (2007). Typology of sociotechnical transition pathways. Research Policy, 36, 399-417.

Hassenforder, E. (2015). Participatory planning, evaluation and institutional dynamics in African Natural Resource Management (NRM). AgroParisTech, IRSTEA, Australian National University. Retrieved from https://openresearchrepository.anu.edu.au/bitstream/1885/101161/1/Hassenforder Thesis 2015.pdf

Hassenforder, E., Ducrot, R., Ferrand, N., Barreteau, O., Daniell, K. A., \& Pittock, J. (2016b). Four challenges in selecting and implementing methods to monitor and evaluate participatory processes: Example from the Rwenzori region, Uganda. Journal of Environmental Management, 180, 504-516.

Hassenforder, E., Pittock, J., Barreteau, O., Daniell, K. A., \& Ferrand, N. (2016a). The MEPPP framework: A framework for monitoring and evaluating participatory planning processes. Environmental Management Journal, 57(1), 79-96. https://doi.org/10.1007/s00267-015-0599-5

Hooghe, L., \& Marks, G. (2004). Contrasting visions of multi-level governance. In I. Bache \& M. Flinders (Eds.), Multi-level Governance. Oxford: Oxford University Press. https://doi.org/10.1093/0199259259.003.0002

Huntjens, P., Pahl-Wostl, C., \& Grin, J. (2010). Climate change adaptation in European river basins. Regional Environmental Change, 10(4), 263-284.

IAEG-SDGs. (2016). Report of the Inter-Agency and Expert Group on Sustainable Development Goal Indicators (E/CN.3/2016/2/Rev.1), Annex IV. New York. Retrieved from https://unstats.un.org/sdgs/iaeg-sdgs/report-iaeg-sdgs/

IAP2. (2007). IAP2 core values of public participation. Retrieved November 5, 2014, from http://www.iap2.org.au/about-us/about/core-values

Kluvankova-Oravska, T., Chobotova, V., Banaszak, I., Slavikova, L., \& Trifunovova, S. (2009). From government to governance for biodiversity: the perspective of transition countries of CEE. Environmental Policy and Governance, 19(3), 186196.

Lovell, C., Mandondo, A., \& Moriarty, P. (2002). The question of scale in integrated natural resource management. Ecology and Society, 5(2), 25.

Lubell, M. (2013). Governing institutional complexity: the ecology of games framework. Policy Studies Journal, 41(3), 537-559.

Marshall, G. (2007). Nesting, subsidiarity, and community-based environmental governance beyond the local scale. International Journal of the Commons. Retrieved from http://www.thecommonsjournal.org/index.php/ijc/article/viewArticle/50

OECD. (2011). Water Governance in OECD Countries: A Multi-level Approach. Paris.

OECD. (2015). Stakeholder Engagement for Inclusive Water Governance. Paris. 
Author-produced version of the article published in International Journal of Water Resources Development, 2018, 35(3), p. 525-542. The original publication is available at https://www.tandfonline.com/doi/full/10.1080/07900627.2018.1452722

Doi: $10.1080 / 07900627.2018 .1452722$

Onyach-Olaa, M. (2003). The challenges of implementing decentralisation: recent experiences in Uganda. Public Administration and Development, 23(1), 105-113.

Ostrom, E. (1999). Coping with tragedies of the commons. Annual Review of Political Science, 2, 493-535.

Pahl-Wostl, C. (2015). Water Governance in the Face of Global Change: From Understanding to Transformation. Springer.

Pahl-Wostl, C., \& Knieper, C. (2014). The capacity of water governance to deal with the climate change adaptation challenge: using fuzzy set Qualitative Comparative Analysis to distinguish between polycentric, fragmented and centralized regimes. Global Environmental Change, 29, 139-154.

Poolman, M., \& van de Giesen, N. (2006). Participation; rhetoric and reality - The importance of understanding stakeholders based on a case study in Upper East Ghana. International Journal of Water Resources Development, 22(4), 561-573.

Rowe, G., \& Frewer, L. J. (2000). Public Participation Methods: A Framework for Evaluation. Science, Technology \& Human Values, 25(1), 3-29.

Susskind, L. (2013). Water and democracy: new roles for civil society in water governance. International Journal of Water Resources Development, 29(4), 666677. Retrieved from http://hdl.handle.net/1721.1/88248

UNECE. (1998). The United Nations Economic Commission for Europe (UNECE) Convention on Access to Information, Public Participation in Decision-Making and Access to Justice in Environmental Matters. Aarhus, Denmark.

UNESCAP. (2009). What is good governance? Bangkok. Retrieved from http://www.unescap.org/sites/default/files/good-governance.pdf

Varis, O., Enckell, K., \& Keskinen, M. (2014). Integrated water resources management: horizontal and vertical explorations and the "water in all policies" approach. International Journal of Water Resources Development, 30(3), 433-444. https://doi.org/10.1080/07900627.2014.912130

Young, O. R. (2008). Institutions and Environmental Change: The Scientific Legacy of a Decade of IDGEC Research. In Institutions and Environmental Change, Principal Findings, Applications, and Research Frontiers (pp. 3-45). Cambridge, MA: MIT Press.

Hassenforder, E., Ducrot, R., Ferrand, N., Barreteau, O., Daniell, K. A., \& Pittock, J. (2016). Four challenges in selecting and implementing methods to monitor and evaluate participatory processes: Example from the Rwenzori region, Uganda. Journal of Environmental Management, 180, 504-516.

Hassenforder, E., Pittock, J., Barreteau, O., Daniell, K. A., \& Ferrand, N. (2016). The MEPPP framework: A framework for monitoring and evaluating participatory planning processes. Environmental Management Journal, 57(1), 79-96. http://doi.org/10.1007/s00267-015-0599-5 
Author-produced version of the article published in International Journal of Water Resources Development, 2018, 35(3), p. 525-542. The original publication is available at https://www.tandfonline.com/doi/full/10.1080/07900627.2018.1452722

Doi: $10.1080 / 07900627.2018 .1452722$

Havekes, H., F. Koemans, R. Lazaroms, D. Poos and R. Uijterlinde (2004), Water Governance: The Dutch Water Board Model, Dutch Association of Water Boards, The Hague.

Hooghe, L., \& Marks, G. (2004). Contrasting visions of multi-level governance. In I. Bache \& M. Flinders (Eds.), Multi-level Governance. Oxford: Oxford University Press. http://doi.org/10.1093/0199259259.003.0002

Hooper, B. (2005). Integrated River Basin Governance. London: IWA Publishing.

H.R.3039 - Chesapeake Bay Restoration Act of 1999

Huntjens, P., Pahl-Wostl, C., \& Grin, J. (2010). Climate change adaptation in European river basins. Regional Environmental Change, 10(4), 263-284.

Abrami, G., Ferrand, N., Morardet, S., Murgue, C., Popova, A., De Fooij, H., ... AquaeGaudi, W. (2012). Wat-A-Game, a toolkit for building role-playing games about integrated water management. In R. Seppelt, A. A. Voinov, S. Lange, \& D. Bankamp (Eds.), iEMSs Sixth Biennial Meeting. Leipzig, Germany. Retrieved from http://www.iemss.org/society/index.php/iemss-2012-proceedings

Bache, I., \& Flinders, M. (2004). Multi-level Governance. (I. Bache \& M. Flinders, Eds.). Oxford: Oxford University Press.

Cash, D. W., Adger, W. N., Berkes, F., Garden, P., Lebel, L., Olsson, P., ... Young, O. (2006). Scale and cross-scale dynamics: governance and information in a multilevel world. Ecology and Society, 11(2), 8.

CGIAR. (2015). Nile Basin Development Challenge Wikispace - Innovation Platforms. Retrieved from http://nilebdc.wikispaces.com/innovationplatforms

Cullen, B., Tucker, J., Snyder, K., Lema, Z., \& Duncan, A. (2014). An analysis of power dynamics within innovation platforms for natural resource management. Innovation and Development, 4(2), 259-275. https://doi.org/10.1080/2157930X.2014.921274

Daniell, K. A., \& Barreteau, O. (2014). Water governance across competing scales: Coupling land and water management. Journal of Hydrology, 519(C), 2367-2380. https://doi.org/10.1016/j.jhydrol.2014.10.055

Ducrot, R., Morardet, S., Hassenforder, E., Abrami, G., Johnston, R., D’Hayer, T., ... Ferrand, N. (2014). A process oriented approach to craft operational strategies for INRM at meso-scale - Operational strategies for adaptation and vulnerability reduction to global change D7.1. Draft version. Brussels, Belgium.

Etienne, M. (2011). Companion modelling A participatory approach to support sustainable development. (M. Etienne, Ed.). Versailles, France: Editions Quae.

European Parliament. (2000). Directive 2000/60/EC of the European Parliament and of the Council establishing a framework for the Community action in the field of water policy. Brussels. Retrieved from http://eur-lex.europa.eu/legalcontent/EN/TXT/PDF/?uri=CELEX:02000L0060-20141120\&from=EN 
Author-produced version of the article published in International Journal of Water Resources Development, 2018, 35(3), p. 525-542. The original publication is available at https://www.tandfonline.com/doi/full/10.1080/07900627.2018.1452722

Doi: $10.1080 / 07900627.2018 .1452722$

Fereday, J., \& Muir-Cochrane, E. (2006). Demonstrating Rigor Using Thematic Analysis: A Hybrid Approach of Inductive and Deductive Coding and Theme Development. International Journal of Qualitative Methods, 5(1), 80-92.

Ferrand, N., Daniell, K. A., Popova, A., Ribarova, I. S., \& Coad, P. (2010). Multilevel Participatory modelling for integrated planning and water management. In Global Conference on Agricultural Research for Development - Workshop "A way to promote adaptive management of rural socio-ecological systems in multi-scale context: participatory modelling." Montpellier.

Ferrand, N., Farolfi, S., Abrami, G., \& Du Toit, D. (2009). WAT-A-GAME: sharing water and policies in your own basin. In "Learn to Game, Game to Learn", ISAGA 40th Annual Conference. Singapore.

Ferrand, N., Hare, M., \& Rougier, J.-E. (2006). Iskar Test Site Option Description Living with Flood and Drought. Methodological document to the Iskar Test Site, AquaStress IP, FP6, Europe. Brussels, Belgium.

Ferrand, N., Hassenforder, E., Abrami, G., \& Aquae-Gaudi, W. (2015). Integrated participatory modeling using the CoOPLAaGE toolkit. In Lamsade \& U. P. Dauphine (Eds.), International Workshop on Citizen Science. Paris. Retrieved from dimacs.rutgers.edu/Workshops/Citizen/Slides/EmelineHASSENFORDER.pdf

Folke, C., Hahn, T., Olsson, P., \& Norberg, J. (2005). Adaptive governance of SocialEcological Systems. Annual Review of Environment and Resources, 30(1), 441473. https://doi.org/10.1146/annurev.energy.30.050504.144511

Geels, F. W., \& Schot, J. (2007). Typology of sociotechnical transition pathways. Research Policy, 36, 399-417.

Hassenforder, E. (2015). Participatory planning, evaluation and institutional dynamics in African Natural Resource Management (NRM). AgroParisTech, IRSTEA, Australian National University. Retrieved from https://openresearchrepository.anu.edu.au/bitstream/1885/101161/1/Hassenforder Thesis 2015.pdf

Hassenforder, E., Ducrot, R., Ferrand, N., Barreteau, O., Daniell, K. A., \& Pittock, J. (2016). Four challenges in selecting and implementing methods to monitor and evaluate participatory processes: Example from the Rwenzori region, Uganda. Journal of Environmental Management, 180, 504-516.

Hassenforder, E., Pittock, J., Barreteau, O., Daniell, K. A., \& Ferrand, N. (2016). The MEPPP framework: A framework for monitoring and evaluating participatory planning processes. Environmental Management Journal, 57(1), 79-96. https://doi.org/10.1007/s00267-015-0599-5

Hooghe, L., \& Marks, G. (2004). Contrasting visions of multi-level governance. In I. Bache \& M. Flinders (Eds.), Multi-level Governance. Oxford: Oxford University Press. https://doi.org/10.1093/0199259259.003.0002

Huntjens, P., Pahl-Wostl, C., \& Grin, J. (2010). Climate change adaptation in European river basins. Regional Environmental Change, 10(4), 263-284.

IAEG-SDGs. (2016). Report of the Inter-Agency and Expert Group on Sustainable Development Goal Indicators (E/CN.3/2016/2/Rev.1), Annex IV. New York. 
Retrieved from https://unstats.un.org/sdgs/iaeg-sdgs/report-iaeg-sdgs/

IAP2. (2007). IAP2 core values of public participation. Retrieved November 5, 2014, from http://www.iap2.org.au/about-us/about/core-values

Kluvankova-Oravska, T., Chobotova, V., Banaszak, I., Slavikova, L., \& Trifunovova, S. (2009). From government to governance for biodiversity: the perspective of transition countries of CEE. Environmental Policy and Governance, 19(3), 186196.

Lovell, C., Mandondo, A., \& Moriarty, P. (2002). The question of scale in integrated natural resource management. Ecology and Society, 5(2), 25.

Lubell, M. (2013). Governing institutional complexity: the ecology of games framework. Policy Studies Journal, 41(3), 537-559.

Marshall, G. (2007). Nesting, subsidiarity, and community-based environmental governance beyond the local scale. International Journal of the Commons. Retrieved from http://www.thecommonsjournal.org/index.php/ijc/article/viewArticle/50

OECD. (2011). Water Governance in OECD Countries: A Multi-level Approach. Paris.

OECD. (2015). Stakeholder Engagement for Inclusive Water Governance. Paris.

Onyach-Olaa, M. (2003). The challenges of implementing decentralisation: recent experiences in Uganda. Public Administration and Development, 23(1), 105-113.

Ostrom, E. (1999). Coping with tragedies of the commons. Annual Review of Political Science, 2, 493-535.

Pahl-Wostl, C. (2015). Water Governance in the Face of Global Change: From Understanding to Transformation. Springer.

Pahl-Wostl, C., \& Knieper, C. (2014). The capacity of water governance to deal with the climate change adaptation challenge: using fuzzy set Qualitative Comparative Analysis to distinguish between polycentric, fragmented and centralized regimes. Global Environmental Change, 29, 139-154.

Poolman, M., \& van de Giesen, N. (2006). Participation; rhetoric and reality - The importance of understanding stakeholders based on a case study in Upper East Ghana. International Journal of Water Resources Development, 22(4), 561-573.

Rowe, G., \& Frewer, L. J. (2000). Public Participation Methods: A Framework for Evaluation. Science, Technology \& Human Values, 25(1), 3-29.

Susskind, L. (2013). Water and democracy: new roles for civil society in water governance. International Journal of Water Resources Development, 29(4), 666677. Retrieved from http://hdl.handle.net/1721.1/88248

UNECE. (1998). The United Nations Economic Commission for Europe (UNECE) Convention on Access to Information, Public Participation in Decision-Making and Access to Justice in Environmental Matters. Aarhus, Denmark.

UNESCAP. (2009). What is good governance? Bangkok. Retrieved from 
http://www.unescap.org/sites/default/files/good-governance.pdf

Varis, O., Enckell, K., \& Keskinen, M. (2014). Integrated water resources management: horizontal and vertical explorations and the "water in all policies" approach. International Journal of Water Resources Development, 30(3), 433-444. https://doi.org/10.1080/07900627.2014.912130

Young, O. R. (2008). Institutions and Environmental Change: The Scientific Legacy of a Decade of IDGEC Research. In Institutions and Environmental Change, Principal Findings, Applications, and Research Frontiers (pp. 3-45). Cambridge, MA: MIT Press.

INBO, \& GWP. (2009). A Handbook for Integrated Water Resources Management in Basins.

Kluvankova-Oravska, T., Chobotova, V., Banaszak, I., Slavikova, L., \& Trifunovova, S. (2009). From government to governance for biodiversity: the perspective of transition countries of CEE. Environmental Policy and Governance, 19(3), 186-196.

Kok, K., Biggs, R. O., \& Zurek, M. (2007). Methods for developing multiscale participatory scenarios: Insights from southern Africa and Europe. Ecology and Society, 12(1), 16.

Lazaroms, R. and D. Poos (2004), "The Dutch water board model", Water Law, Vol. 15, No. 3/4, pp. 137-140.

Lovell, C., Mandondo, A., \& Moriarty, P. (2002). The question of scale in integrated natural resource management. Ecology and Society, 5(2), 25.

Lubell, M. (2013). Governing institutional complexity: the ecology of games framework. Policy Studies Journal, 41(3), 537-559.

Marshall, G. (2007). Nesting, subsidiarity, and community-based environmental governance beyond the local scale. International Journal of the Commons. Retrieved from http://www.thecommonsjournal.org/index.php/ijc/article/viewArticle/50

Metze, M. (1999), Let's Talk Dutch Now: Harmonie in de Polder; Uitvinding of Erfenis?, Arbeiderspers, Amsterdam.

Ministry of Transport, Public Works and Water Management (2010), Water Act, Ministry of Transport, Public Works and Water Management, The Hague.

Molle, F. (2009). River-basin planning and management : the social life of a concept. Geoforum, 40(3), 484-494.

Mowday, R.T.; Steers, R.M. (1979), The measurement of organisational commitment. J. Vocat. Behav. 1979, 14, 224-247.

OECD (2014), Water Governance in the Netherlands: Fit for the Future?, OECD Series on Water, Paris

OECD. (2011). Water Governance in OECD Countries: A Multi-level Approach. OECD Series on Water, Paris. 
OECD. (2015). Stakeholder Engagement for Inclusive Water Governance. Paris.

Ostrom, E. (1990), Governing the Commons: The Evolution of Institutions for Collective Action; Cambridge University Press: Cambridge, United Kingdom.

Ostrom, E. (1999). Coping with tragedies of the commons. Annual Review of Political Science, 2, 493-535.

Ostrom, E. (2010), "Beyond markets and states: Polycentric governance of complex economic systems", American Economic Review, Vol. 100, Issue 3, pp. 641-672, http://dx.doi.org/10.1257/aer.100.3.641.

Oxford Dictionary (2017), British \& World English definition of scale, https://en.oxforddictionaries.com/definition/scale (last consulted on 26 June 2017).

Pahl-Wostl, C. (2015). Water Governance in the Face of Global Change: From Understanding to Transformation. Springer.

Pahl-Wostl, C., \& Knieper, C. (2014). The capacity of water governance to deal with the climate change adaptation challenge: using fuzzy set Qualitative Comparative Analysis to distinguish between polycentric, fragmented and centralized regimes. Global Environmental Change, 29, 139-154.

Pretty, J. (1995), Participatory learning for sustainable agriculture. World Dev. 1995, 23, 1247-1263.

Rowe, G.; Frewer, L.J. (2005), A typology of public engagement mechanisms. Sci. Technol. Hum. Values 2005, 30, 251-290.

RRDF. (2011). Rwenzori Regional Development Framework 2012-2016. Fort Portal, Uganda. Retrieved from http://www.krcuganda.org/wpcontent/uploads/2012/08/Rwenzori-Regional-Framework.pdf

Smith, D.H. (1983),Synanthrometrics: On progress in the development of a general theory of voluntary action and citizen participation. In International Perspectives on Voluntary Action Research; Smith, D.H., Van Til, J., Eds.; University Press of America: Washington, DC, USA.

Swyngedouw, E. (2000). Authoritarian Governance, Power, and the Politics of Rescaling. Environment and Planning D, 18(1), 63-76.

UNECE. (1998). The United Nations Economic Commission for Europe (UNECE) Convention on Access to Information, Public Participation in Decision-Making and Access to Justice in Environmental Matters. Aarhus, Denmark.

UNESCAP. (2009). What is good governance? Bangkok. Retrieved from http://www.unescap.org/sites/default/files/good-governance.pdf

Yee, S. (2010), Stakeholder Engagement and Public Participation in Environmental Flows and River Health Assessment; Project Code P0018, Australia-China Environment Development Partnership, 2010. 